\title{
From Symbols to Numbers: the shifting technologies of education governance in Europe ${ }^{[1]}$
}

\author{
SOTIRIA GREK \\ Centre for Educational Sociology, \\ University of Edinburgh, United Kingdom
}

\begin{abstract}
This article focuses on the changing nature of education governance in Europe. It looks at the shifting discourses and policy practices in the ways in which the European Commission has aligned itself to education and discusses the reasons for what is presented as a substantial shift in the tools and resources for governing the European education space. The article suggests that, alongside other significant developments, the knowledge economy has had two significant effects on education governance in Europe: first, a rapid change of policy discourse and practice, moving from constructing a European 'culture' to a Europe of learning governed by numbers; and second, education is slowly moving from the margins of European governance to the very centre of its policy making. The article discusses the new technologies of governance that have powered this shift and makes a case for the significance of recognising and studying them further.
\end{abstract}

\section{Introduction}

This article focuses on the changing nature of education governance in Europe. It develops in two parts: first, it gives an account of the construction of the European education space as one of a common culture, mainly developed during the 1980s and 1990s; second, it moves on to discuss the changing European education policy landscape after 2000 and the Lisbon agreement. The article looks at the shifting discourses and policy practices in the ways in which the European Commission has aligned itself to education and discusses the reasons for what is presented as a substantial shift in the tools and resources for governing the European education space. The article suggests that, alongside other significant developments, the knowledge economy has, first, brought a rapid change of policy discourse and practice, moving from constructing a European 'culture' to a Europe of learning governed by numbers. Secondly, the article argues that education is slowly moving from the margins of European governance to the very centre of its policy making. What are the technologies that have powered this radical shift? In conclusion, the article discusses this question and poses new ones in the search of a better understanding of education governance in Europe.

\section{Constructing Europe: from Adonnino (1985) to Maastricht (1992)}

Cooperation in the field of education in Europe started as early as the 1970s with the first Community action programme (1975). The first 10 years of its implementation (1976-84) established the processes of the collaboration through transnational pilot projects, study visits and exchanges of information and experience. These developments

engendered a form of cooperation within the Community framework, which, in a way, was the first application of the principle of subsidiarity before it was defined and the first demonstration that it was possible, in a Community that was on the path to integration, to cooperate in areas 
that were fundamental to the structure of the nation states while fully respecting the diversity of national situations and the powers of Member States. (Pépin, 2006, p. 25)

Education, although on the cusp of the Community's broader agenda, was paving the way for integration, not only on the symbolic and discursive plane, but also through cooperation at a policy level, mobilising networks, associations and a number of education players across Europe. The second half of the 1980s would be marked by the emergence of major Community programmes in higher education and vocational training (Pépin, 2006).[2] The Erasmus programme, named after the widely travelled philosopher, theologian and humanist Erasmus of Rotterdam, became the most well known of all and perhaps the symbol of European cooperation in education in the minds of university students across Europe.

In 1983, the European Community heads of government signed the 'Solemn Declaration on European Union' in Stuttgart, inviting Member States to work together in the field of culture in order to promote European identity (Commission of the European Communities, 1983) - these were information, education, audio-visual policy and the arts. A year later, through the Television without Frontiers directive, it was suggested that 'European unification will only be achieved if Europeans want it. Europeans will only want it if there is such a thing as European identity' (Commission of the European Communities, 1984, p. 2). Since there was no legal basis for a specific cultural policy, a number of ad hoc 'cultural actions' were justified for their economic pertinence in the expanding field of the culture industry (Forrest, 1994). The most significant development of the 1980s was the European Council's decision to create an ad hoc Committee for a People's Europe, chaired by the Italian Member of the European Parliament Pietro Adonnino. The committee produced two influential reports (Adonnino, 1985) as part of the project of building Europe: two of their recommendations included strengthening the European cultural sector and providing reciprocal recognition of equivalent diplomas and professional qualifications (Shore, 2000). According to the reports: 'through action in the areas of culture and communication, which are essential to the European identity and the Community's image in the minds of its people, support for the advancement of Europe can and must be sought' (Adonnino, 1985, p. 21). There were suggestions for the foundation of a European Academy of Science, European sports teams, school exchange programmes, voluntary work camps for young people and, in general, the introduction of a stronger European dimension in education, including 'the preparation and availability of appropriate school books and teaching materials' (Adonnino, 1985, p. 24). Ironically, supranational Europe was going through a process of serious nation building. The introduction of the European flag of 12 yellow stars against a blue background became the key symbol in European consciousness raising:

Twelve was a symbol of perfection and plenitude, associated equally with the apostles, the sons of Jacob, the tables of the Roman legislator, the labours of Hercules, the hours of the day, the months of the year, or the signs of the Zodiac. Lastly, the circular layout denoted union.

(Council of Europe, quoted in Shore, 2000, p. 47)

The era of the 'Euro symbols' had begun: the Community funded the formation of a European Community youth orchestra, an opera centre, the conservation of the Parthenon and monasteries in Mount Athos, the European Literature Prize, the European Woman of the Year award, the Jean Monnet Awards, the cultural capitals of Europe, the European Year of the Cinema, the European Year of the Environment - the list can go on (Shore, 2000). Far from transcending the hegemony of the nation-state ideology, the new Europe was being constructed with the tools of what Shore (2000, p. 50) calls a 'conservative current of nineteenth-century social evolutionist thought'. Nairn (1977, p. 16) describes the process of the building of the European identity not as the end of the nation state, but as the creation of a 'super-nation-state founded on European chauvinism'. Retrospectively, it is interesting to note that at the beginning of the 1990s Europe's constructed other was not illegal immigrants from the East, but the wave of Americanisation dominating Europe from the West. Le défi americain (the American challenge) repeatedly appears in Commission discourse and other official documentation as threatening the European common cultural heritage, which, although had deep roots in the history of the European peoples, the Commission still needed to 'defend' and raise 'awareness' around (Shore, 1996). 
At the beginning of the 1990s, the collapse of communism in Eastern Europe and the outlook of German reunification had already led to a commitment to reinforce the Community's international position through the Treaty on European Union, signed on 7 February 1992 and enforced on 1 November 1993. Known as the Maastricht Treaty, it was to become a landmark in the history of European integration as the culmination of the Single European Act of 1985, which established the objective of the common market. In addition, after more than 15 years of activity, the fields of education and culture were acquiring a clear legal basis within the policy framework of the European Union. The Maastricht Treaty was the pinnacle of a series of (mainly) symbolic decisions taken at Community level in the 1980s, such as the issuing of a single European passport, the abolishing of all police and customs formalities for people crossing intra-Community borders, as well as the considerations for the creation of a single flag, a European anthem, European sports teams and the creation of European coinage, namely the ECU (European Council Meeting, Fontainebleau, 1984).

Above all, the Treaty on European Union was the first time that education and culture were being acknowledged as an inherent part of the integration process. Vocational training was slightly weakened in the new arrangement, since it lost its unique standing and became part of the wider framework in the cooperation between education, culture and social work. Although the process had already started in the 1980s, these were the first firm steps in the shift from the 'technocrats' Europe' to a 'Europe of the peoples'. Although Articles 126 and 127 of the Treaty on European Union declared that there would be no harmonisation of European education systems and a common European education model would not be promoted, fields of activity such as language learning, youth exchanges, collaboration amongst educational institutions and especially student and teacher mobility were to receive far greater economic sustenance and policy significance as the 'complementary' competences of the European Union (Treaty on European Union, 1992).

However, although Maastricht had been prepared and awaited for years, after the signing of the treaty, enthusiasm around it dropped; the people of Denmark rejected it completely and it only scraped through a referendum in France (Shore, 2000). The dream of economic collaboration and the creation of a common market, which would eventually lead to the sharing of a common culture and a European consciousness, was increasingly looking rather dim. Europe was looking for a unique identity that would bring its people together. Jean Monnet, one of the founding fathers of the Union, famously suggested that if the European project was to start all over again, it would start from culture (Pépin, 2006). Maastricht signalled the vital ingredient that had been missing from the recipe thus far: legitimacy for the European cause. If there was a need for a Commission, a Parliament, a Council, a Court of Justice and a Central Bank, surely there was a need to create a European demos, a transnational European public whose interests the Union would represent.

Indeed, at the beginning of the 1990s the Union seemed to undergo a deep crisis: its elite administration with its bureaucratic and centralised character did not appear alluring any more. Once again, Europe needed a unifying myth. The common agricultural or competition policy did not appear sufficient to justify the European project - education would have to become the vital ingredient in building the 'people's Europe', in order to 'make people more aware of their European identity in anticipation of the creation of a European cultural area' (Commission of the European Communities, 1988, p. 37).

Europeanisation found in the fields of education and culture some of the most influential carriers of a common European consciousness. By this I do not refer to the legal framework bringing educational systems across Europe closer together. Instead, I mean all those factors, abstract and concrete, formal and informal, individual and collective, which have been slowly changing the ways Europe is represented. These have not only been the official and unofficial representations fostered by the Union or by the Member States themselves. The Erasmus programme, for instance, although already significantly successful by 1992, was to increase the number of student exchanges across Europe during the 1990s to hundreds of thousands. Europe was not just a myth, but a reality for the educational experiences and exchanges of thousands of Europeans.

However, what would distinguish the people of Europe from those in other continents in the increasing globalised world? The Maastricht Treaty had the answer: the creation of the idea of 'European citizenship' would become the new unifying concept for the peoples of Europe, who, apart from being nationals, were now part of this sui generis project - the fabrication of European 
'culture', or the European 'civilisation', as the French preferred. With regard to the field of education, subsidiarity became a popular term; it would ensure the autonomy of education systems across Europe, however only to highlight that they had now become parts of a much larger whole, an almost moral project of Europe, made up by the 'mosaic of the European cultures' - this would involve benefits, but also responsibilities. Weiler's (1999) description of meetings between Commission officials and Member State representatives is an interesting one. Weiler describes the general atmosphere of the meetings as one of a superior supranational idealist meeting an inferior state realist:

The Community official may have been earning a lot more than his or her national counterpart and enjoying working conditions and a social package which was the envy of all national administrations, but he or she was also occupying the high moral ground: a true public servant. (Weiler, 1999, p. 254)

Socrates and Leonardo, the two new education programmes with significant amounts of funding (933 million ECU for Socrates and 794 million ECU for Leonardo), were also included in the pantheon of names of eminent European scholars. They both ran from 1995 to 1999. Socrates had the objective 'to contribute to the development of quality education and training and the creation of an open European area for cooperation in education' and, in particular, 'develop the European dimension in education in order to promote citizenship' (Pépin, 2006, p. 170). It followed three strands: higher education (Erasmus), school education (Comenius) and language learning (Lingua). The instruments of cooperation, according to the programme, would be institutional contracts, transnational projects, mobility and networks. Leonardo aimed at implementing a Community vocational training programme, signalling the increasing significance given to the development of lifelong learning in the knowledge society. Both programmes were continued for a second phase (2000 to 2006) and have now been replaced by the new Lifelong Learning programme - the first time that, rather than a scholarly, a more 'pragmatic' name has been given to a European education programme.

However, as already stated, public support for the European Union in the 1990s was dropping. The De Clercq report (1993, p. 2) stated that 'European identity has not yet been engrained in people's minds'; that, by adopting a more 'human face, sympathetic, warm and caring', Europe had to be promoted as a 'brand' product, in order to speak to the hearts of European individuals:

The Commission should be clearly positioned as the guarantor of the well being and quality of life of the citizen of Europe ... must be brought close to the people, implicitly evoking the maternal, nurturing case of 'Europa' for all her children. (De Clercq, 1993, p. 9)

European citizens were now segmented into 'target audiences', with journalists and media people as the 'priority target groups' of 'Euro-marketing'. In fact, with the Greek dictatorship's tactics still fresh in the memory, a Greek journalist, Costas Verras, president of the Brussels International Press Association, publicly protested, accusing the Commission of 'behaving like a military junta' (Booker \& North, 1996, p. 165). However, as with the old empires, the arrival of success for the Union had perhaps already sown the seeds of a crisis. Due to enlargement and globalisation, debates were soon to change the focus of the integration process from uniting the peoples of Europe under a common destiny to finding urgent and joint responses to new challenges. According to Pépin:

It was now more necessary than ever to create this 'ever closer union among the people of Europe' which had been asserted since the beginning by successive treaties and could not be achieved by economic integration alone. The globalisation of trade and the information and communication technologies had an ever greater impact on how and where knowledge was transferred, education and training systems being at the top of the list. (Pépin, 2006, p. 156)

Indeed, as early as 1994, the White Paper Growth, Competitiveness and Employment (Pépin, 2006) supported the need to take action in the field of lifelong learning. In 1995, the White Paper Teaching and Learning: towards the learning society had already begun constructing the Europe of the future. Europe's culture and civilisation appeared of less significance in this new official discourse: 'Tomorrow's society will be a society which invests in knowledge, a society of teaching and 
learning, in which each individual will build up his or her own qualifications. In other words, a learning society' (European Commission, 1995, p. 2).

\section{Measuring Europe: Lisbon (2000) and after}

Indeed, 'learning' and the 'knowledge society' were soon to become the new dominant discourses in the process of fabricating the space of European education. Even though an interest in measuring educational performance through numerical data was evident as early as the mid 1970s [3], the concepts of indicators and benchmarking received the European education ministers' explicit attention for the first time in 1999 at a conference in Prague. The ministers adopted a resolution with a view to new working methods for cooperation in education and training which would increase 'continuity, effectiveness and efficiency of education in Europe' (Council of Europe, 1999). They stressed the need for a more coherent approach for all Community action and for a structured framework for political discussion and activities over the coming years. The conference theme focused on the quality of school education; the ministers decided to set up a group of national experts who would devise a list of indicators of quality in school education in Europe. According to the Commission:

the objective was not to create new indicators in such a short time but to identify the quality-

related problems which were politically most relevant for European countries, and then

determine which of the existing indicators - mainly from Eurostat, the OECD [Organisation for

Economic Co-operation and Development], the IEA [4] and Eurydice - could shed most light on these problems. (Pépin, 2006, pp. 196-197)

The 16 indicators for quality assurance (Pépin, 2006) prepared by the group of experts were not devised from scratch. They were constituted on the basis of triangulating existing data that at this point were deemed useful; in a sense, most of the work towards establishing the new quality assurance framework for European education was already in place. What was necessary now was to coordinate data, organisations and minds towards the requirements of the new knowledge economy.

In the field of higher education, the Bologna process (1999) set out to achieve a consistent and compatible European area of higher education by 2010 with the introduction of a simplified system of more transparent and comparable degrees across Europe. This would entail the convergence of national systems under a common framework of Bachelor's and Master's degrees and doctorates (Corbett, 2005). In addition, the European Credit Transfer and Accumulation System (ECTS), which had already been devised for the needs of the Erasmus programme, had to be taken into account, as well as ensuring European cooperation in quality assurance. A medium-term action plan was devised for the implementation of the Bologna declaration - the Council of Europe described it as 'the most important and wide-ranging reform of higher education since 1968' (cited in Pépin, 2006, p. 197).

However, the turning point towards an increased interest in setting standards for education systems in Europe was the Lisbon Council of 2000. According to the Presidency Conclusions: 'the European Union is confronted with a quantum shift resulting from globalisation and the challenges of a new knowledge-driven economy' (Council of the European Union, 2000). Apart from setting specific objectives, such as an increased investment in human resources, the establishment of a European framework for lifelong learning and the fostering of educational mobility, the Council also suggested a new style of policy formation, the 'open method of coordination' (OMC) (Council of the European Union, 2000). Indicators and benchmarking are at the heart of this policy tool, since the OMC was declared as the new 'soft' form of governance.

Nonetheless, apart from establishing new strategic goals and the policy frameworks to push them, the Lisbon Council was significant for one more reason: it was the first time that the Council promoted the need for European education systems to converge. As already discussed, such dialogue, especially in the fields of lifelong learning, vocational training and higher education, had been long under way. However, the coordination of European education systems at the level of compulsory schooling was a fairly new endeavour. Indeed, although the Lisbon Treaty was essentially an economic treaty, apart from focusing on employment and economy (the two more 
'traditional' areas for joining efforts in the past) it was the education ministers who were appointed this time with the mission to achieve the Lisbon goals for 2010.

According to the official European Commission overview of the pre- and post-Lisbon developments, the quantification of certain aspects of school life was regarded as a positive step forward:

While the setting of quantified targets is not unusual in areas such as employment or the economy, it was a very new and bold step at European level in a field like education. Targets have the merit of being explicit and making it easier to assess the progress made. (Pépin, 2006, p. 208)

Whilst numbers are fairly easily collected, they do require a firm basis for comparison and crosssystemic analysis of the data; the development of discourses for the justification of measuring specific indicators and benchmarking would soon come to fulfil this need.

Indeed, a year later, the Education Council asked the Commission to draft a report on the 'concrete future objectives of education and training systems' (Council of the European Union, 2001). The report set out 13 objectives to be achieved by 2010 and, according to the Commission, it was 'the first official document sketching a comprehensive and coherent European approach to national education and training policies in the EU' (European Commission, 2002, quoted in Pépin, 2006, p. 209). It was signed at the 2001 Stockholm European Council by the Commission and it was agreed that a detailed work programme on how to achieve the new goals would be planned. The objectives came under three strategic goals: education and training in Europe should by 2010, according to the report, become more effective, with improved quality, accessibility and openness (European Commission, 2002a). The heads of states and governments approved the work programme in 2003 and committed themselves to the new vision for European education: a 'world quality reference' by 2010. It was the first time in the history of the European education space that no reference was made to the common European cultural or educational heritage - the focus now was on a projected image of a competitive and social Europe.

The work programme for 2010 was also the first time the OMC was applied as a governing tool. It involved the measuring of progress against objectives and the exchange of information and good practice. Hence, the added importance which was given to transparency and evaluation would initiate a different kind of coordination of the European education systems. Instead of the 1999 'rolling agenda' of reforms (Pépin, 2006), according to the Commission, the OMC 'has the potential to pave the way for coherent policies in areas such as education where a formal common policy is not appropriate but where enhanced cooperation and mutual learning at European level can add real value' (European Commission, 2002b, p. 16). In other words, alongside the old methods of networking and exchanging good practice, a concrete set of standards would now act as the new governing technology in the field of European education. From now on, the production of statistical reports by Member States would double. New categories of educational structures were being invented, such as participation in compulsory schooling or learning to learn. A different European education space was in the making; it would be governed by numbers and quality standards.

Apart from statistics, the OMC became the stimulus for other initiatives in the creation of the basis for the measurement and comparison of the European education systems. One of these first initiatives was to set up nine working groups of national experts and a Standing Group on Indicators and Benchmarks. Information exchange, study visits and shared ideas of good practice would guide the work of the groups for the next three years (European Commission, 2003a). Although networks of professionals were the main agents of cooperation before, it was the first time that committees of experts from the Member States had officially been given the task of devising common standards for all European education systems. This 'magistracy of influence' (Lawn \& Lingard, 2001) consisted of people who would work solely on furthering the European dimension of education, to ensure high quality and relevance, and improve the effectiveness of education and training in Europe. In some ways, the problems of harmonisation and subsidiarity were now to be faced not only by Commission officials but mainly by representatives from the Member States themselves.

However, despite the new framework of action, the acceleration of Asian economies (mainly China and India), the enlargement of the European Union in 2004 and the ever-dominant pressures 
for securing social cohesion and promoting European citizenship led to new challenges. According to the first Commission report regarding the progress of the 'Education and Training 2010' agenda (European Commission, 2003b), there was an urgency to implement the Lisbon goals, since data were presenting an alarming picture with regard to a number of indicators for European education systems. In the light of the Kok report (European Commission, 2004), which warned about the very modest achievements in relation to 'Education and Training 2010', the Commission adopted a reformed strategy towards 'Education and Training 2010', with the focus on stricter growth and employment objectives. The 'technocrats' Europe' was striking back.

\section{Conclusions}

According to Anders Fogh Rasmussen, Prime Minister of Denmark, commenting on the Treaty of Lisbon: 'the good thing is that all the symbolic elements are gone, and that which really matters the core - is left' (Jyllands-Posten, 2000, quoted in Shore, 2000). As discussed above, all the European 'symbolic elements' after the Lisbon Treaty were indeed gone for good. It seems that 'the core' - quality and efficiency - is not to be merely found as the central component of European education policy in the post-Lisbon era; it has been the core and the periphery and everything education - or, to be accurate, lifelong learning - is about. Although the Euro symbols of the 1980s, the Erasmus programme and other constructs of the older European 'common culture' project still hold strong, the language of numbers has gained an 'extraordinary' significance, as a top official from the Commission has argued:

And because of Lisbon ... the work on indicators exploded. I think I had one person or two, I had one person working on the indicators, that was the person that took care of all of this ... So we developed that slowly and I think that now, five, seven years later we have about, between 40 and 50 people working in the field. Inside the Commission ... It is exploding. Extraordinary. (EU3)[5]

For a long time in the history of the European education space, education governance was exercised through 'technologies of the self (Foucault et al, 1988), which had systematically been working towards establishing new normative categories and constructing new meanings: these were notions like 'common European values', 'common culture', or the notion of 'Europeanness'. According to Shore (2000, p. 30): 'constructing Europe requires the creation of "Europeans", not simply as an objectified category of EU passport holders and "citizens", but, more fundamentally, as a category of subjectivity". This article has shown the modernist approaches taken in the construction of a European subjectivity, which, by often being astonishingly direct and almost propagandistic, were sometimes harshly criticised and rejected (Delanty, 1995). The old European myth was indeed a myth of high, elitist European culture, a myth of Enlightenment ideals commonly created and treasured by the European peoples - white middle- or upper-class men, in their majority. Nevertheless, these ideals had a strong social dimension which became particularly appealing and promising after the devastation and despair of the two world wars. The Member States of the Union were invited in a project to build a social Europe which would establish itself as the significant other against the inhumanity of an economic system of winners and losers that was accelerating to global dominance.

However, it soon turned out that the 'people's Europe' was not sufficient to respond to the demands of the new millennium. Despite subsidiarity, the field of education served for over three decades in the project of the creation of a European common identity. In history and geography, in narratives and tradition, Europe became a classical value - education and culture, through overemphasising commonalities and sidelining differences, were handy crutches in lifting the idea of Europeanisation.

At the same time, national education systems remained more or less the same; they welcomed exchanges and networks as the additional European 'extra', which offered a fresher flavour of cosmopolitanism in their somewhat stale school curricula of the old Europe. Despite the systematic efforts to create a common European education space, education in the pre-Lisbon era remained largely a national topic. In the face of globalisation and the dominance of the knowledge economy, new and urgent technologies of persuasion had to be devised; the voluntary nature of the previous arrangement was too loose to respond to the severe economic challenges of both 
education and the wider market. Creating, regulating and monitoring or, in other words, governing the European education space now had to be based on statistics and what Rose (1991) calls 'governing by numbers'. In fact, one of the greatest post-Lisbon developments in the history of the European Union is the weight given to education and training in Europe. First, for the European Union, rather than an area at the periphery of policy making, education and learning have now become central in constructing Europe itself. Europe does not need to pre-exist in the hearts and minds of the people as it did before - it is being created, sorted, systematised, scrutinised and constantly improved through the new soft governance tools of comparison and benchmarking. Hard European Union regulation, in areas such as agriculture or trade, for example, often meets the resistance and criticism of Euro-sceptics. On the other hand, 'soft' law (Lawn, 2003) is selfimposed and self-adhered; it is effective, manageable and economical; it looks optional and 'light touch'; it seems objective and forward-looking; it relates to current concerns. Second, for the Member States, in the field of education, Europe has become the relatively friendlier face of globalisation: it gives them a platform to raise their voices; it offers them a quality assurance framework, which many of them would otherwise have to devise on their own; it often provides them with best practice advice, leaving the content of the curriculum intact; and, above all, it offers them a scapegoat for undisputedly justifying the necessity for modernisation and reform.

However, no matter how misguided Euro-romantics have been, Rasmussen is also seriously wrong - the 'core' is not stripped of ideological and symbolic weight. The new technology of the governance of the European education space through indicators and benchmarks is not only to be seen as the project of fulfilling Brussels' requirements of achieving specific goals and objectives. Instead, it has to be examined as deeply penetrating consciousness-moulding and thus the serious business of constructing new categories of (educational) thought and action - the project of reinventing a 'new' European identity of competitive advantage and responsible individualism. According to Hacking (1991, p. 194): 'the bureaucracy of statistics imposes not just by creating administrative rulings but by determining classifications within which people must think of themselves and of the actions that are open to them'. At their best, these new governance technologies have offered a more coherent and organised framework for the improvement of the quality of education systems across Europe; at their worst, they are simply transforming education cultures and traditions, every aspect of teaching and learning, into tables and graphs, devoid of meaning, political context or any sense of history and place.

Nevertheless, on the ground and in the classroom, there has been significant resistance to the narrowing down of education in sets of standards and quality controls across Europe. Interview data from the research project this article builds on suggest that at least in five European countries [6] - despite their relatively long tradition of quality assurance and evaluation systems - 'governing by numbers' has often led to distrust and a lack of professional judgment, a massive amount of labour for the production of data but limited analysis and use of it, and the more general feeling that the 'quality' discourse masks real intentions for surveillance and the reshaping of education systems as competitive markets.[7] Although statistics were initially welcomed as a viable method to ensure progress in key areas such as education spending, there is widespread scepticism about their capacity to fully capture the multilayered problems and contradictions of education practice. Above all, statistics do not convey much about the context in which data are interpreted; policy makers are too ready to find quick-fix solutions to problems which might need far closer scrutiny and understanding. Data prompt fast action; understanding the context around them requires time and debates that can neither be afforded nor are desired. Above all, numbers have become an objective, irreversible 'truth'; context could only complicate or question that truth, hence it is unwelcome. According to a key European policy actor:

The way the data are interpreted, the way they are used, the way we use them at EU level is crucial for the issue of the quality of the system because it can have a perverse effect if it is too narrow perspective ... Quality and efficiency can really not be measured without having elements which are more reliable, based only on the figures that we have so far. But it is a political will to do it so the policy makers have to be more open and patient to qualitative information. My fear is that there is a tendency because of the pressure of time, because of the decisions that they have to make that they finally decide on data which are largely insufficient or too narrow. Really too narrow, and we should not encourage that. (EU4)[8] 
Lawn argues that:

Losing national reference points and a sense of national purpose or destiny while at the same time being situated in a raw state of marketization or commodification raises questions about how the EU can successfully invent a new identity with its own mission and purpose, developing and legitimating itself. (Lawn, 2003, p. 327)

This is true. However, before entering a debate about the purposes and values of education governance in contemporary Europe, this article has attempted to show the significance of understanding that the shift to 'governing by numbers' is not merely a discursive, cosmetic or surface change, but in fact could be understood as the very process which has become one of the central components of building the new Europe of the knowledge economy. There seems to be a serious imbalance in the history of the construction of the European education space: from almost obsessively focusing on the 'big' history of a very remote past that belonged to few and was of interest to even fewer, Europe has turned to almost an anxiety to forecast, control and shape a oneway future. There is now an urgent need to recognise and further study the meaning of this shift in order to capture its full impact on the future of education governance both at the European Union and the national levels.

\section{Acknowledgements}

My sincere thanks go to Professors Jenny Ozga and Martin Lawn for their insightful comments on earlier drafts of this article.

\section{Notes}

[1] This article is based on ongoing research in the project Governing by Numbers/ Fabricating Quality in European Education, which is part of the European Science Foundation's Eurocores project; the United Kingdom element is funded by the Economic and Social Research Council (RES-00-23-1385). More information about the project, and access to its working papers, can be found at: http: / / www.ces.ed.ac.uk/ research/FabQ/index.htm

[2] These projects were: Comett (1986), focusing on cooperation between universities and industry; Erasmus (1987), focusing on university cooperation and student mobility; PETRA (1987), focusing on training and transition from school to work (later to be incorporated by the Leonardo programme); Youth for Europe (1988), based on youth exchanges across Europe; Lingua (1989), promoting the teaching of foreign languages; Eurotecnec (1989), focusing on innovation in vocational training in connection with technological change; FORCE (1990), focusing on continuing training; and, finally, after the major political changes at the end of the decade, Tempus (1990), a 'tailor-made' programme focusing on mobility in higher education for the countries of central and eastern Europe.

[3] A European Commission resolution emphasised the significance of information sharing between Member States and the need for education statistics (Official Journal of the European Communities, C38, 19.2.1976). Eurostat started publishing data from national statistics in 1978, nonetheless it was only after the 1990s that it began producing more statistically comparable data.

[4] This is the International Association for the Evaluation of Educational Achievement. Since its inception in 1958, the IEA has conducted more than 23 research studies of cross-national achievement. Examples are the Trends in International Mathematics and Science Study (TIMSS, 1995, 1999, 2003, 2007) and the Progress in International Reading Literacy Study (PIRLS, 2001, 2006).

[5] Code name for the Commission official who was interviewed in June 2007 as part of the project 'Governing by Numbers/ Fabricating Quality in European Education'.

[6] These are Denmark, England, Finland, Scotland and Sweden.

[7] For example, across the five countries there has been an emphasis on self-evaluation, either understood as an addition to other quality assurance practices (like hard performance indicators) or taken as a substitute for more strict and centralised forms of governance. For example, in the case of England, school self-evaluation evidence has become the starting point for inspections; in Denmark, it has come to be considered as a fixed element in the evaluations conducted by the Danish Evaluation Institute. The Scottish system of self-evaluation prescribes indicators rather than self- 
chosen goals. Further, in Finland and Sweden respectively, the municipal providers of education are obliged to evaluate what they provide, but not in any particular or fixed fashion. What appears to be most significant is not the discourse or the variations on practice, but that the local space for manoeuvre has been considerably narrowed by the increased production of data and statistics. More examples and a discussion of the different trends may be found in the special issue of the Journal of Education Policy, 'Governing by Numbers - Making Europe?' (2008, under review).

[8] Code name for the ex-Eurydice official who was interviewed in June 2007 as part of the project 'Governing by Numbers/Fabricating Quality in European Education'.

\section{References}

Adonnino, P. (1985) A People's Europe: reports from the ad hoc committee, Bulletin of the European Communities, Supplement 7/85.

Booker, C. \& North, R. (1996) The Castle of Lies. London: Duckworth.

Commission of the European Communities (1983) Solemn Declaration on European Union, European Council, Stuttgart, 19 June 1983, Bulletin of the European Communities, 6, 24-29.

Commission of the European Communities (1984) Television without Frontiers. Green Paper on the Establishment of the Common Market for Broadcasting, especially by Satellite and Cable, COM (84) final. Luxembourg: Office for Official Publications of the European Communities.

Commission of the European Communities (1988) A People's Europe. Communication from the Commission to the European Parliament, COM (88) 331 final, 7 July, Bulletin of the European Communities, Supplement 2.

Corbett, A. (2005) Universities and the Europe of Knowledge. New York: Palgrave Macmillan.

Council of Europe (1999) 'Into the New Millennium': developing new working procedures for European cooperation in the field of education and training, Official Journal of the European Communities, 8, 12 January 2000.

Council of the European Union (2000) Lisbon European Council 23 and 24 March 2000, Presidency Conclusions. http://www.europarl.europa.eu/summits/lis1_en.htm

Council of the European Union (2001) The Concrete Future Objectives of Education and Training Systems, 5980/01 EDUC. http:/ / ec.europa.eu/education/policies/2010/doc/rep_fut_obj_en.pdf

De Clercq, W. (1993) Reflection on Information and Communication Policy of the European Community. Brussels: Commission of the European Communities.

Delanty, G. (1995) Inventing Europe: idea, identity, reality. London: Macmillan.

European Commission (1995) Teaching and Learning: towards the learning society. Brussels: European Commission.

European Commission (2002a) Education and Training in Europe: diverse systems, shared goals for 2010. The Work Programme on the Future Objectives of Education and Training Systems. Brussels: Directorate-General for Education and Culture.

European Commission (2002b) The Future Development of the European Union Education, Training and Youth Programmes after 2006: a public consultation document. Brussels: Directorate-General for Education and Culture.

European Commission (2003a) Implementation of 'Education and Training 2010' Work Programme. Brussels: Directorate-General for Education and Culture.

European Commission (2003b) Commission Staff Working Document - Implementation of the 'Education and Training 2010' programme. Supporting document for the draft joint interim report on the implementation of the detailed work programme on the follow-up of the objectives of education and training systems in Europe. Brussels: Directorate-General for Education and Culture.

European Commission (2004) 'Education \& Training 2010' - the success of the Lisbon Strategy hinges on urgent reforms. Joint Interim Report of the Council and the Commission on the implementation of the detailed work programme on the follow-up of the objectives of education and training systems in Europe. Brussels: Directorate-General for Education and Culture

Forrest, A. (1994) A New Start for Cultural Action in the European Community: genesis and implications of Article 128 of the Treaty of the European Union, Cultural Policy, 1(2), 11-20.

Foucault, M., Martin, L.H., Gutman, H. \& Hutton, P.H. (1988) Technologies of the Self: a seminar with Michel Foucault. Amherst: University of Massachusetts Press. 
Hacking, I. (1991) How Should We Do the History of Statistics? In G. Burchell, C. Gordon \& P. Miller (Eds) The Foucault Effect: studies in governmentality. London: Harvester Wheatsheaf.

Lawn, M. (2003) The 'Usefulness' of Learning: the struggle over governance, meaning and the European education space, Discourse, 24(3), 325-336. http: / / dx.doi.org/10.1080/0159630032000172515

Lawn, M. \& Lingard, B. (2001) Constructing a European Policy Space in Educational Governance: the role of transnational policy actors, European Educational Research Journal, 1(2), 290-307.

Nairn, T. (1977) The Break-up of Britain. London: New Left Books.

Pépin, L. (2006) The History of European Cooperation in Education and Training: Europe in the making-an example. Luxembourg: Office for Official Publications of the European Communities.

Rose, N. (1991) Governing by Numbers: figuring out democracy, Accounting, Organizations and Society, 16(7), 673-692. http: / / dx.doi.org/10.1016/0361-3682(91)90019-B

Shore, C. (1996) Transcending the Nation-State? The European Commission and the (Re-)discovery of Europe, Journal of Historical Sociology, 9(4), 473-496. http: / / dx.doi.org/10.1111/j.1467-6443.1996.tb00108.x

Shore, C. (2000) Building Europe: the cultural politics of European integration. London: Routledge.

Treaty on European Union (1992). http: / / europa.eu/eur-lex/en/treaties/dat/EU_treaty.html\#0001000001

Weiler, J.H.H. (1999) The Constitution of Europe: 'Do the New Clothes Have an Emperor?' and other essays on European integration. Cambridge: Cambridge University Press.

SOTIRIA GREK is a Research Fellow at the Centre for Educational Sociology, University of Edinburgh, United Kingdom. Her research interests include education governance, education and European integration, analysis of educational policy discourse and the political economy of education. Correspondence: Dr Sotiria Grek, Centre for Educational Sociology, University of Edinburgh, St John's Land, Holyrood Road, Edinburgh EH8 8AQ, United Kingdom (sotiria.grek@ed.ac.uk). 